\title{
Destination wise Export Performance of India
}

\author{
Dr. Narinder Kaur ${ }^{1}$, Dr. Reetu Kapoor ${ }^{2}$ \\ ${ }^{I}$ (Principal, University College, Meerapur, India) \\ ${ }^{2}$ (Assistant Professor of Commerce, Govt. Bikram College of Commerce, Patiala, India.)
}

\begin{abstract}
International business has assumed complex dimensions. Exports have assumed a paramount importance in the development process of the economy. This paper gives an insight into the performance of India's exports in terms of changes in world demand and market distribution. The study analysis these components by dividng the time period into three phases namely 1990-91 to 1999-00, 2000-01 to 2007-08 and for the overall period of 1990-91 to 2007-08. In order to know the actual performance of exports data has been converted into constant prices. Simple growth rates, trend base growth rates and Ginni's coefficient of concentration have been used as the tools of analysis. Further t test has also been applied to check the statisticial significance level. The results show frequent fluctuations in the geographical concentration index. The trend value is also negative and insignificant which indicates unfavourable changes in geographical distribution of exports for India.
\end{abstract}

Keywords- Concentration Index, Destinationwise, Export Diversification, Export Performance, Gini coefficient of concentration, Growth Rate.

\section{INTRODUCTION}

Exports are the main resources for a developing country to achieve a rapid growth. Exports help in enlarging the size of the market extending the international division of labour and specialization and scale of production. The strategic importance of export trade in economic development of an underdeveloped country is beyond any argument.

Export as a challenging task no longer remains confined to meet the perfect market requirements in terms of quality, price, competitiveness and committed delivery schedules. In the present era of increasing competition, aggressive innovative marketing strategies have widened its sphere to the development of business ties and proper service support. With the increasing trade disparities between the developed and the developing economies, heavy debt-burden and balance of payments problem of the developing countries, the international trade today is full of uncertainties. This situation further deteriorates the position of developing economies because it gives the constant pressure upon these countries to increase export earnings to meet their debt commitments. This calls for modernsisation of production, cost reduction and ensuring of better quality products.

The export performance of a country is determined by the growth in world demand. Export promotion being one of the main factors for economic growth. It is prerequisite for adequate foreign exchange earnings to maintain the economic development. The key to viable balance of payments is strong and sustained export growth and an efficient import substitution.

\section{LITERATURE REVIEW}

Econimists have written quite extensively on the subject of exports and economic development. The following studies have been undertaken in the literature review to study the high elasticity of supply and high elasticity of demand for exports for the extensive research purpose.

Konya and Singh (2008), investigated empirically the presence of an equilibrium relationship between the logarithms of Indian exports and imports between the period of 1949-50 and 2004-2005. The results indicated no cointegration between exports and imports. The lack of co-integration meant that Indian macroeconomic policies were ineffective in bringing exports and imports into long-run equilibrium and India was in violation of her international budget constraint.

Bhat and Paul (2009) examined the trends and patterns of import intensity in the whole economy and manufacturing sector in India during 1990s and beyond based on input-output tables. The study found that import intensity of exports has increased in late 1990s as compared with early 1990s. The study found an overall increase in import intensity for most of the broad sectors of the economy as well as many branches of the manufacturing sector in 2003-04 as compared to $1998-99$.

Taneja (2010), analyzed the impact of downturn of world economy on Indian Export Sector, particularly on the exports of principle items and suggested few strategies to promote India's exports for a sustainable long term growth. The study found that India's merchandise exports, after recording a steady growth of $33.7 \%$ during AprilAugust 2008, witnessed deceleration in September 2008. Subsequently, exports recorded a decline. She concluded that 
India after liberalization almost achieved high export growth rate but during global crisis Indian export sector was badly hit.

Mukherjee and Mukherjee (2012) analysed the performance of India's exports and the various economic factors which contributed to its growth. The study revealed that since manufacturing sector generated large scale employment for low and medium skilled workers, it was imperative to develop features which would create a congenial environment for industries to grow further. They also identified the various inadequacies which prevailed within the sector.

Goldar (2013), examined the factors behind the significant increase in import intensity of India's manufactured exports that has taken place in the post-reform period. The industry-level analysis indicated that the increase in import intensity of manufactured exports was attributable partly to changes in product composition of exports and partly to growing export orientation of Indian manufacturing industries.

Pathania (2013) studied the relationship between exports, imports and gross domestic capital formation in India with popular time series econometric techniques during 1991 to 2010 . The results of the co-integration test based on Johansen's procedure indicated the existence of the co-integration between exports and imports, export and gross domestic capital formation and import and gross domestic capital formation.

Azharuddin and Paramanik (2014) investigated the growth-export relationship of the Indian economy through three variables IIP, EXP and WPI during April 1998 to November 2012. The pair wise Granger causality test suggested that there was no causal relation between the growth of IIP and growth of export. The study was of view that although in the long-run there was a stable equilibrium relationship between IIP and exports, there was no causal relationship between the growths of exports to growth of IIP.

Singla and Singh (2014) examined the various trends occurred in growth and structure of Indian exports to China during the last two decades. The analysis revealed the major changes in the composition and direction of Indian exports. China's share in India's global exports increased rapidly from just 0.10 per cent in 1990-91 to 6.47 per cent in 2009-10. The study found India's ability to compete with other nations was of great importance in determining its share in the world trade which would be a more critical factor in sustaining the higher rates of growth of the economy.

Zaki,Chahir (2015) evaluated the effect of different aspects of trade facilitation in developed and developing countries on bilateral trade through an augmented gravity model and used the latter to estimate ad valorem equivalents (AVEs) of administrative barriers to trade. The results revealed that a multitude of trade facilitation variables including internet, bureaucracy, corruption and geography affected the transaction times to import and transaction times to export.

\section{NEED OF THE STUDY}

A number of the studies have been undertaken to analyze India's export performance and export instability. Most of studies, some of them referred above, have been conducted in this area. But these, mostly, concentrate on the possible impact of instability on economic growth. Moreover these studies do not take into account economic variables on times series basis, rather they draw inferences in a cross-sectional framework. Thus, the present study is an attempt to fill this gap.

\section{OBJECTIVES OF THE STUDY}

The main objective of this study is to examine the issue of diversification of country's export pattern in terms of markets. So, the present study aims at finding out the performance of India's exports. For this purpose export performance in term of changes in world demand and market distribution have been examined have been examined.

\section{RESEARCH METHODOLOGY}

Research methodology is the specification of methods of acquiring the information needed to structure or solve the problems in hand. By methodology of any research means the selection of the representative sample, collection of relevant data, application of appropriate research tools and techniques of analysis, and interpretation of the same for scientific investigation of the problem. In the present study to curb the impact of inflation the analysis has been done at constant prices. For this purpose financial figures given at current prices have been deflated by using export unit value index.

\section{Period of Study}

The study covers the post liberalisation period of twenty three years i.e. from 1990-91 to 2013-14 for the analysis of export performance in India.

\section{Data Collection}

The study is primarily based on secondary data. A plethora of data has been collected from the national as well as international sources. Director General of Commercial Intelligence and Statistics (DGCIS), Reserve Bank of India, 
United Nations Conference on Trade and Development (U.N.C.T.A.D.), International Monetary Fund (I.M.F.), Various Statistical Abstracts of Government of India, Economic Survey, Ministry of Finance, Government of India, New Delhi.

\section{TOOLS OF ANALYSIS}

For finding out growth in exports, basically two types of growth rates have been used. These growth rates are as under: Simple Growth Rate: Here percentage growth rate over the previous year has been calculated to analyze the trends from year to year basis. The percentage growth rate over the previous year is given as:

$$
\mathrm{GR} \% \quad=\frac{\mathrm{Vc}-\mathrm{Vb}}{\mathrm{Vb}}
$$

Where: $\quad V c=$ Value of the given parameter in the current year.

$\mathrm{Vb}=$ Value of the given parameter in the base year.

Trend Growth Rate: It has been worked out for a period on the basis of value for all the years. It is considered to be a better estimate. In the study, least square trend is fitted for the given years and the least squares trend growth rate has been calculated by using the following exponential relationship

$$
\mathrm{Y}=\mathrm{AB} \mathrm{t}
$$

Where ' $\mathrm{Y}$ ' is the variable of exports value for which compound rate of growth is calculated and $t$ is time period. Where $\mathrm{A}$ is the $\mathrm{Y}$ intercept and $\mathrm{B}$ is the slope of the curve.

$$
\mathrm{B}=1+\mathrm{r}
$$

Where ' $\mathrm{r}$ ' is the compound growth rate and the growth rate in percentage form shall be equal to:

$$
\mathrm{r}(\%)=(\mathrm{B}-1) \times 100
$$

T-test:

T-test has been used to test the significance of growth rate.

$$
t=r \sqrt{\frac{N-2}{1-r^{2}}}
$$

Where $\mathrm{r}$ is correlation coefficient,

$\mathrm{N}$ is the number of observations and

$\mathrm{N}-2$ gives the degree of freedom.

To find out the real growth in exports, the exports value for various years has been deflated with the overall unit value index of exports.

\section{Gini coefficient of concentration:}

The degree of concentration for exports has been measured by Gini coefficient of concentration. The coefficient of geographic concentration is defined as under:

$$
\mathrm{G} x_{\mathrm{t}}=100 \sqrt{\sum_{\mathrm{i}=1}^{\mathrm{n}}\left(\frac{\mathrm{X}_{\mathrm{it}}}{\mathrm{X}_{\mathrm{t}}}\right)^{2}}
$$

$\mathrm{Xit}$ is the value of exports to country $\mathrm{i}$ in the year $\mathrm{t}$ and

$\mathrm{Xt}$, as defined earlier, is the total export earnings during the year $\mathrm{t}$.

The highest possible value of the coefficient is 100 which occurs when exports consists of only one good. The value of the coefficient of concentration will be lower, the more evenly exports are distributed over the various possible categories and the lowest value of the coefficient is $\frac{100}{\sqrt{n}}$ Where $\mathrm{n}$ is the number of different countries.

\section{RESULTS AND DISCUSSIONS}

\section{India's Share of Exports in World Exports:}

Foreign trade has been an important factor to promote the economic growth in India. Its impact can be segregated in both positive and negative effects through growth model for four decades. Table I deals with the world exports and India's exports which tells about the Indian share in the world trade. It is seen from the table that India's export as percentage of world's exports has increased during the study period. The table enumerates that in the year 1990-91, India's exports stood at 17.97 U.S. million dollars while the world export stood at 3376.6 U.S. million dollars. So, in 
this particular year India's export share as percentage of world exports was 0.53 percent. This ratio slightly came down to 0.51 percent in the year 1991-92 and 0.52 percent in the year 1992-93. But afterwards, this ratio kept on increasing as compared to the ratio in the base year (0.53 percent in 1992-93). The India's exports in the year 2013-14 stood at 314.66 U.S. million dollars while the world export stood at 18459.28 U.S. million dollars. So, in this particular year India's export share as percentage of world exports was 1.70 percent which shows growth of 220.75 percent in India's export as percentage of world exports during the study period. This growth rate is the result of the adoption of the globalization policy which led to improved exports. Although in early 1990s, India had passed through serious economic crisis, which disrupted the backbone of its economy and caused high inflation and shortage of foreign exchange reserves but exports during this time period never gave the gloomy picture which is a very positive sign for Indian economy.

Table I World Exports and India's Exports (U.S. Million Dollar)

\begin{tabular}{|c|ccc|}
\hline Year & World Exports & India's Exports & $\begin{array}{c}\text { India's Export as a \% of world } \\
\text { exports }\end{array}$ \\
\hline $1990-91$ & 3376.6 & 17.97 & 0.53 \\
$1991-92$ & 3477.5 & 17.66 & 0.51 \\
$1992-93$ & 3731.4 & 19.56 & 0.52 \\
$1993-94$ & 3767.7 & 21.6 & 0.57 \\
$1994-95$ & 4289.9 & 25.0 & 0.58 \\
$1995-96$ & 5130.3 & 30.6 & 0.60 \\
$1996-97$ & 5169.2 & 33.1 & 0.64 \\
$1997-98$ & 5539.1 & 35.0 & 0.63 \\
$1998-99$ & 5454.5 & 33.4 & 0.61 \\
$1999-00$ & 5648.6 & 35.7 & 0.63 \\
$2000-01$ & 6373.0 & 42.4 & 0.67 \\
$2001-02$ & 6140.1 & 43.4 & 0.71 \\
$2002-03$ & 6434.1 & 50.4 & 0.78 \\
$2003-04$ & 4783.8 & 59.0 & 0.79 \\
$2004-05$ & 9107.0 & 76.6 & 0.84 \\
$2005-06$ & 10460.8 & 99.6 & 0.95 \\
$2006-07$ & 12139.0 & 120.9 & 1.00 \\
$2007-08$ & 13842.4 & 145.4 & 1.05 \\
$2008-09$ & 15926.4 & 181.86 & 1.14 \\
$2009-10$ & 12366.8 & 176.76 & 1.42 \\
$2010-11$ & 15064.9 & 222.57 & 1.48 \\
$2011-12$ & 18013.3 & 302.89 & 1.68 \\
$2012-13$ & 18068.17 & 296.83 & 1.64 \\
$2013-14$ & 18459.28 & 314.66 & 1.70 \\
\hline
\end{tabular}

Source: International Monetary Fund, International Financial Statistics, Washington, D. C. and Government of India, Economics Survey, Various issues, New Delhi.

\section{Export Performance in Major Markets:}

Directorial changes in India's exports provide us a deeper insight into the pattern of growth of many categories of exports. Table II summarizes the trends in the direction of India's exports during the period 1990-91 to 2007-08 for major countries at constant prices. The table reveals that in 1990-91 Former Russia had maximum share in world exports. It was 16.14 percent in 1990-91. The share of Former Russia fell down in the other phases. It was 2 percent in 1999-2000 and 0.58 percent in 2007-08 respectively. U.S.A. was placed at second place in 1990-91 and its share was 14.7 percent. Then there was a hike in the later years. Its percentage share was 20.9 percent in 1999-00 which registered a decline in 2007-08 and stood with the share of 12.71 percent. Although the percentage share fell down in the year 2007-08 but still U.S.A. was capable to get the first rank. The share of U.K. was 6.6 percent in 1990-91. It declined to 5.2 percent in 1990-91 and further recorded a fall and reached to 4.11 percent in 2007-08. The share of Belgium and Germany also declined from 1990-91 to 2007-08. The share of Netherlands, Iran, Africa and Latin America recorded a significant increase from 1990-91 to 2007-08. The places captured by these countries namely Netherlands, Africa, Iran and Latin America stood at second, seventh and twelfth positions in India's exports in 1990-91where and Iran and Latin America contributed with the same percentage share. These four countries secured fifth, second, tenth, and fourth place in 2007-08 respectively. U.S.A. had maximum share 20.9 percent in 1999-00 and 12.71 percent in 2007-08 respectively. In 1990-91 Iran and Latin America captured the bottom ranks. In 1999-00 Iran was at bottom while in 2007-08, Former Russia got the lowest ranking. 
The trend growth rates of major countries have also been shown in table II during the three phases namely 1990-91 to 1999-00, 2001-08 and for the overall period of 1990-91 to 2007-08. In 1990-91 U.S.A., U.K., Belgium, Netherlands, Canada, Australia, Saudi Arabia, Africa, and Latin America, Germany had registered significant level of growth. From 2000-01 to 2007-08 U.K., Germany, Netherlands, Australia, Saudi Arabia, Africa and Latin America, U.S.A., Iran had significant level of growth. From 1990-91to 2007-08 U.S.A., U.K., Belgium, Germany, Netherlands, Australia, Saudi Arabia, Africa, and Latin America, Canada and Iran had significant level of growth. In 1990s Latin America (29.63\%) had highest growth rate and Russia $(-6.47 \%)$ had lowest growth rate. During 2000s Iran (36.79\%) had highest growth rate and Germany $(4.11 \%$ ) had lowest growth rate in India's exports. The situation is not the same for the third phase. In 1990-91 to 2007-08 Latin America had highest growth rate with 24.12 percent share while Russia had lowest growth rate registered with -3.94 percent share. The overall growth rate of total exports in majors markets was 10.82 in $1990 \mathrm{~s}$, 12.43 in 2000s and 11.61 in 1990-91 to 2007-08 respectively. All the growth rates were found statistically significant at $5 \%$ level of significance.

Table II India's Exports to Major Markets at Constant Prices (Base 1978-79=100)

\begin{tabular}{|c|c|c|c|c|c|c|}
\hline & \multicolumn{3}{|c|}{$1990-91$} & \multicolumn{3}{|c|}{ 1999-00 } \\
\hline & $\begin{array}{c}\text { Value } \\
\text { (Rs.crore) }\end{array}$ & $\begin{array}{c}\text { Share } \\
\%\end{array}$ & Rank & $\begin{array}{c}\text { Value } \\
\text { (Rs.crore) }\end{array}$ & $\begin{array}{r}\text { Share } \\
\%\end{array}$ & Rank \\
\hline U.S.A. & 4797 & 14.7 & 2 & 36380 & 20.9 & 1 \\
\hline U.K. & 2128 & 6.6 & 5 & 8817 & 5.2 & 2 \\
\hline Belgium & 1259 & 3.9 & 6 & 5926 & 3.3 & 5 \\
\hline Germany & 2549 & 7.8 & 4 & 7533 & 4.3 & 3 \\
\hline Netherlands & 644 & 2 & 8 & 3838 & 2 & 8 \\
\hline Canada & 281 & 0.9 & 11 & 2506 & 1.5 & 11 \\
\hline Australia & 321 & 1 & 10 & 1748 & 0.9 & 12 \\
\hline Japan & 3039 & 9.3 & 3 & 7303 & 4 & 4 \\
\hline Iran & 141 & 0.4 & 12 & 659 & 0.5 & 13 \\
\hline Saudi Arabia & 419 & 1.3 & 9 & 3218 & 1.8 & 10 \\
\hline Russia & 5255 & 16.14 & 1 & 4108 & 2 & 8 \\
\hline Africa & 668 & 2.1 & 7 & 4841 & 3.2 & 6 \\
\hline Latin America & 132 & 0.4 & 12 & 2674 & 2.1 & 7 \\
\hline $\begin{array}{l}\text { Total Exports } \\
\text { (including others) }\end{array}$ & 32553 & 100 & 13 & 159561 & 100 & 13 \\
\hline
\end{tabular}

\begin{tabular}{|c|c|c|c|c|c|c|}
\hline & \multicolumn{3}{|c|}{ 2007-08 } & \multicolumn{3}{|c|}{ Growth Rate } \\
\hline & $\begin{array}{c}\text { Value } \\
\text { (Rs.crore) }\end{array}$ & $\begin{array}{c}\text { Share } \\
\%\end{array}$ & Rank & $\begin{array}{l}1990-91 \\
1999-00\end{array}$ & $\begin{array}{l}2000-01 \\
2007-08\end{array}$ & $\begin{array}{l}1990-91 \\
2007-08\end{array}$ \\
\hline U.S.A. & 83388 & 12.71 & 1 & $15.02 * *$ & $8.81 *$ & $10.98 * *$ \\
\hline U.K. & 26965 & 4.11 & 3 & $9.38 * *$ & $6.32 * *$ & $8.50 * *$ \\
\hline Belgium & 15748 & 2.58 & 7 & $10.12 * *$ & 5.67 & $9.04 * *$ \\
\hline Germany & 20599 & 3.14 & 6 & $5.26 *$ & $4.11 * *$ & $5.33 * *$ \\
\hline Netherlands & 21038 & 3.21 & 5 & $12.67 * *$ & $12.75^{* *}$ & $12.01 * *$ \\
\hline Canada & 5094 & 0.78 & 11 & $18.67 * *$ & 6.43 & $11.59 *$ \\
\hline Australia & 4630 & 0.71 & 12 & $11.59 * *$ & $5.67 * *$ & $8.54 * *$ \\
\hline Japan & 15516 & 2.37 & 8 & 2.08 & 10.02 & 1.68 \\
\hline Iran & 7845 & 1.2 & 10 & 7.91 & $36.79 *$ & $18.26^{*}$ \\
\hline Saudi Arabia & 14923 & 1.66 & 9 & $13.83 * *$ & $4.44 * *$ & $12.67 * *$ \\
\hline Russia & 3784 & 0.58 & 13 & -6.47 & 11.94 & -3.94 \\
\hline Africa & 46463 & 5.77 & 2 & $17.19 * *$ & $13.41 * *$ & $19.32 * *$ \\
\hline Latin America & 22778 & 3.47 & 4 & $29.63 * *$ & $17.74 * *$ & $24.12 * *$ \\
\hline $\begin{array}{l}\text { Total Exports } \\
\text { (including others) }\end{array}$ & 655864 & 100 & 13 & $10.82 * *$ & $12.43 * *$ & $11.61 * *$ \\
\hline
\end{tabular}

Source: DGCIS Calcutta.

Notes: All growth rate are semi -logarithmic least square trends .

*Statistically significant at 5 percent level

**Statistically significant at 1 percent level 


\section{Trends in Majors Regions:}

In the economy, the attempts to liberalize external trade are meant to create export opportunities by allowing the trade with different regions. Table 2.2 deals with India's exports to measure regions at constant prices. It summarizes the trends in the direction of India's exports during the period 1990-91 to 2007-08. This table reveals that the percentage share of East European countries (EEC) and Asia and Oceania (A\&O) has declined from 1990-91 to 2007-08. In 199091 European Union got the first rank. During this period the shares of E. U. and Asia and Oceania stood at 27.5 percent and 10.4 percent respectively. But in 2007-08, the shares registered a fall and came down to 21.26 percent and 2.96 percent respectively. Thus the recorded fall in the shares of these two regions was 22.69 percent and 71.54 percent respectively.

The share of North America was 15.6 percent in 1990-91. Firstly it registered an increase with 22.4 percent share in 1999-00 and then recorded a decline with 19.24 percent share in 2007-08. But for O.P.E.C. and Others the case is somewhat different. The shares of O.P.E.C. and Others have increased in all the three phases of time period. For O.P.E.C. the percentage share stood at 5.6 percent during 1990-91 which increase to the tune of 10.9 percent in 1999-00 and further increased to 13.19 percent during 2007-08. In the same way for others the percentage share was 16.8 percent in 1990-91 which increased to 26.7 percent during 1999-00 and again it recorded a hike with 29.41 percent share in 2007-08. The table further reveals that E.U. which captured first rank during 1990-91 came down to second rank during 1999-00 and in 2007-08. Others have taken a lead in India's exports to major regions by being at number one position during 1999-00 and in 2007-08.

The trend base growth rates of the values of majors regions have also been shown in table II. During the period of study in all the three phases of time period i.e. 1990-91, 2000-01and 1990-91 to 2007-08 others have maintained the highest rate of growth. During the first phase of time period i.e. 1990-91 Asia and Oceania have recorded lowest growth rate to the tune of 3.16 percent while others have recorded highest growth rate to the tune of 15.92 percent. In the second phase of time period i.e. 2000-01 O.P.E.C. has recorded the lowest rate of growth to the tune of -7.64 percent while others have recorded highest growth rate to the tune of 20.55 percent. During the third phase of time period i.e. from 1990-91 to 2007-08 Asia and Oceania have recorded the lowest rate of growth to the tune of 2.48 percent while others have recorded highest growth rate to the tune of 17.48 percent. So, the analysis reveals that others have maintained their lead in India's export to major regions at constant prices during the study period. In 1990-91 E.U., North America, Others, O.P.E.C. and Asia and Oceania have registered significant growth rates. In 2000-01 E.U. and Others have recorded significant growth rates. During the third phase of time period i.e. from 1990-91 to 2007-08 E.U., North America and Others have recorded significant level of growth rates. Table II further reveals that total exports have also recorded significant level of growth during the study period.

Table III India's Exports to Major Regions at Constant Prices (Base 1978-79 = 100)

\begin{tabular}{|l|ccc|ccc|}
\hline & \multicolumn{3}{|c|}{$1990-91$} & \multicolumn{3}{c|}{ 1999-00 } \\
\cline { 2 - 7 } & $\begin{array}{c}\text { Value } \\
\text { (Rs.crore) }\end{array}$ & $\begin{array}{c}\text { Share } \\
\%\end{array}$ & Rank & $\begin{array}{c}\text { Value } \\
\text { (Rs.crore) }\end{array}$ & $\begin{array}{c}\text { Share } \\
\%\end{array}$ & Rank \\
\hline E.U. & 8951 & 27.5 & 1 & 39445 & 22.7 & 2 \\
North America & 5077 & 15.6 & 3 & 38886 & 22.4 & 3 \\
OPEC & 1831 & 5.6 & 5 & 16910 & 10.9 & 4 \\
Asia \& Oceania & 3401 & 10.4 & 4 & 9330 & 5.1 & 5 \\
Others & 5465 & 16.8 & 2 & 40906 & 26.7 & 1 \\
\hline Total Exports & 32553 & 100 & 5 & 159561 & 100 & 5 \\
(including others) & & & & & & 5 \\
\hline
\end{tabular}

\begin{tabular}{|c|c|c|c|c|c|c|}
\hline & \multicolumn{3}{|c|}{$2007-08$} & \multicolumn{3}{|c|}{ Growth Rate } \\
\hline & $\begin{array}{c}\text { Value } \\
\text { (Rs.crore) }\end{array}$ & $\begin{array}{r}\text { Share } \\
\%\end{array}$ & Rank & $\begin{array}{c}1990-91 \\
\text { to } \\
1999-00\end{array}$ & $\begin{array}{c}2000-01 \\
\text { to } \\
2007-08\end{array}$ & $\begin{array}{c}1990-91 \\
\text { to } \\
2007-08\end{array}$ \\
\hline E.U. & 138859.8 & 21.26 & 2 & $9.16 * *$ & $11.75 * *$ & $9.40 * *$ \\
\hline North America & 88482 & 19.24 & 3 & $13.38 * *$ & 5.11 & $10.39 * *$ \\
\hline OPEC & 26603.6 & 13.19 & 4 & $14.08 *$ & -7.64 & 5.87 \\
\hline Asia \& Oceania & 20145.72 & 2.96 & 5 & $3.16^{*}$ & 3.58 & 2.48 \\
\hline Others & 283751 & 29.41 & 1 & $15.92 * *$ & $20.55^{* *}$ & $17.48 * *$ \\
\hline $\begin{array}{l}\text { Total Exports } \\
\text { ( including others) }\end{array}$ & 655863.5 & 100 & 5 & $10.82 * *$ & $12.43 * *$ & $11.61 * *$ \\
\hline
\end{tabular}

Source: DGCIS, Calcutta. 
Notes: (i) All growth rates are semi-logarithmic least square trends

(ii) Asia \& Oceania includes Australia and Japan, and others include Africa, Asia and Latin America.

* Statistically significant at 5 percent level

**Statistically significant at 1 percent level

Besides this, the direction of the trade sector of India with the rest of the world has been increasing and has passed the message that liberalization is having a positive impact on India's economic growth, which can undoubtedly be observed from the empirical discussion above. The findings of the study support the argument in favor of the liberalisation policy and positively respond to the issue that India should open up at faster pace. The analysis shows that rice, fish and fish preparations; and tea have insignificant role in our exports. Furthermore, gems and jewellery, chemical and allied products and machinery transport and metal manufactures are the commodities for which attempts should be made to increase production. This study gives the result that the structure of exports has been changed. The share of traditional commodities has declined and the share of non-traditional commodities has increased during the study period.

In order to measure the overall trend of diversification, a study of concentration of exports is important so as to indicate the degree of dependence upon commodities and countries.

India's Export Concentration

The degree of concentration has been measured by Ginni's co-efficient of concentration which has been used by different economists namely Hirschman, Michaely, Massell and Stern. The coefficient of geographic concentration for exports is shown in table III the table shows that the geographic concentration index for exports has been fluctuating. The trend value is negative and insignificant. This apparently indicates unfavourable changes in geographical distribution of exports for India.

Table IV Geographic Concentration of India's Exports to Major Countries

\begin{tabular}{|c|c|c|c|}
\hline Year & Exports (Gx) & Year & Exports (Gx) \\
\hline $1990-91$ & 26.26 & $1999-00$ & 25.19 \\
\hline $1991-92$ & 23.50 & $2000-01$ & 23.12 \\
\hline $1992-93$ & 23.79 & $2001-02$ & 21.82 \\
\hline $1993-94$ & 22.58 & $2002-03$ & 22.66 \\
\hline $1994-95$ & 23.35 & $2003-04$ & 20.65 \\
\hline $1995-96$ & 21.69 & $2004-05$ & 19.01 \\
\hline $1996-97$ & 32.56 & $2005-06$ & 19.48 \\
\hline $1997-98$ & 22.67 & $2006-07$ & 18.23 \\
\hline $1998-99$ & 25.51 & $2007-08$ & 16.23 \\
\hline & & Trend value & -0.43 \\
\hline
\end{tabular}

Notes: (i) Commodities included constitute 42.29 percent in 2007-08.

Source: DGCIS, Calcutta.

India's overall growth rate remained same during the study period 1990-91 to 2007-08. Oil Cake, gems and jewellery, chemical and allied products, machinery, transport and metal manufactures had almost stabilizing growth rate which was significant at $5 \%$ level of significance. Tea and handicraft had an insignificant role in our exports.

Moreover, in this study it has been found that the importance of traditional commodity was declining because its share in world exports' has been falling since 1990s. India is a developing country, which has vast potential to excel. The development strategy also accounts for the increase in non-traditional commodities from the year 1991. The nontraditional commodities are one the main factors in promoting the economic growth for the Indian economy.

\section{CONCLUSION}

Exports have acquired added significance in the wake of liberalization wave sweeping across the world. The trend towards market economy in almost all the countries of the world has increased the role of exports in the development efforts. Exports have become an important indicator of a country's economic performance. Although non-traditional items have entered into India's exports in a big way but traditional items also occupy a dominant place in our export basket.

The study analyzes that U.S.A., U.K., Belgium, Germany, Netherlands, Australia, Saudi Arabia, Africa, Latin America, Canada and Iran had significant level of growth. Latin America (24.12 percent) had highest growth rate and Russia (3.94 percent) had lowest growth rate. The overall growth rate of total export in majors markets was 11.61 in 1990-91 to 2007-08. All the three phases had significant level of growth. 
The percent share of East European countries and Asia and Oceania declined from 1990-91 to 2007-08. O.P.E.C. and Others have increased their share from 1990-91 to 2007-08. In 1990s the share of both of these countries was 5.6 percent and 16.8 percent but it was increased and reached to the level of 13.19 percent and 29.41 percent during 200708 respectively. In 1990-91 E.U. got the first rank and others had the highest trend growth rate. From 1990-91 to 200708 Asia and Oceania (2.48 percent) had the lowest rate of growth. From 1990-91to 2007-08 E.U., North America and Others had significant level of growth. However total exports also had significant level of growth.

By earnings foreign exchange, exports play an important role in the development process of the country. Exports have played a major role in generating investible surplus and in financing imports. Shortage of foreign exchange is considered a major constraint on rapid economic development of less developed countries. In view of liberalization and globalization of Indian economy, it must be realized that reduction in trade deficit is to be brought only through increase in export. Export-led growth strategy has to be followed and exports have to be made national effort.

\section{REFERENCES}

[1] S. M. Azharuddin and R. N. Paramanik, Revisiting Growth-Export Nexus of Indian Economy, Asian Journal of Research in Social Sciences and Humanities, 4(4), April 2014, 61-73.

[2] J.N. Bhagwati, and T.N. Srinivasan, Foreign Trade Regimes and Economic Development in India (National Bureau of Economic Research: New York, 1975).

[3] T.P. Bhat, and M. Paul, Measurement of Import Intensity of Exports in India, The Journal of income and wealth, 31(1), January-June 2009, 8192.

[4] B. Goldar, Determinants of Import Intensity of India's Manufactured Exports under the New Policy Regime, Indian Economic Review, 48(1), 2013, 221-237.

[5] L. Konya and J. P. Singh, Are Indian Exports and Imports Cointegrated? Applied Econometrics and International Development, 8(2), 2008, 177-186.

[6] J. S. Mah, Export Expansion, Economic Growth and Causality in China, Applied Economics Letters, 12(2), 2005, 105-107

[7] S. K. Mallick and H. Marques, Pricing to Market with Trade Liberalization: The Role of Market Heterogeneity and Product Differentiation in India's Exports, Elsevier: Journal of International Money and Finance, 31(2), 2012, 310-336.

[8] S. Mukherjee and S. Mukherjee, Overview of India' Export Performance: Trends and Drivers, Indian Institute of Management Bangalore, Working Paper 363 (April 2012), 1-63.

[9] R. Nallathiga, From Import Substitution to Export Promotion: The Changing Contours of Economic Policy, the Asian Economic Review, L (3), (December 2008), 495-510.

[10] R. Pathania, Linkages between Export, Import and Capital Formation in India”, International Research Journal of Social Sciences, 2(3), March 2013, 16-19.

[11] A. V. Rajwade, Risks \& Rewards of Capital Account Convertibility, Economic \& Political Weekly, XLII(1), 6 January 2007, 29-34.

[12] A. Samarpitha, Growth and Instability in Area, Production and Productivity of Major Pulses in Andhra Pradesh, Radix International Journal of Research of Social Science, 2(10), Oct. 2013, 1-8.

[13] Y. K. Singh and R. B. Bajpai, Research Methodology-Techniques \& Trends (APH Publishing Corporation: New Delhi, 2007).

[14] S. K. Singla and M. Singh, An Analysis of India's Export Performance with China (1991-2010), Research J. Humanities and Social Sciences, 5(2), April-June 2014, 154-162.

[15] Nisha Taneja, Trade Facilitation: Issues and Concerns, Economic and Political Weekly, 39(1-30), 2004, 126-128.

[16] Rashmi Taneja, Global Recession and Turnaround Strategies for India's Export Sector, Mangalmay Journal of Management \& Technology, 4(2), July-December 2010, 56-64

[17] Aviral Kumar Tiwari, Are exports and imports cointegrated in India and China? An empirical analysis, Economics Bulletin, 31(1), March 2011, 860-873.

[18] M. Upender, Long Run Equilibrium between India's Exports and Imports During 1949-50 - 2004-05" Applied Econometrics and International Development, 7(1), 2007, 187-196.

[19] C. Veeramani, Sources of India's Export Growth in Pre- and Post-Reform Periods, Economic \& Political Weekly, 42(25), 23-29 June 2007, 2419-2427.

[20] Ravinder Vinayek and Reeti Gupta, Corporate Websites as a New Export Marketing Tool for Indian Exporters: An Evaluation, Osmania Journal of International Business Studies, 5(1\&2), Jan.-June \& July-Dec. 2010, 42-48.

[21] Charan Wadhva, India's Export Performance and Policy, 1951-74 and planning for the Future up to 1981, in Wadhva (Ed.), some problems of India's economic policy: selected readings on planning, agriculture, and foreign trade, (New Delhi: Tata McGraw-Hill Publishing Company Limited., 1977), 620-653.

[22] Sangeeta Yadav and Manjula Mishra, Trade Liberalisation and Export Performance: Estimation of Elasticities, Management \& Change, 12 (2), 2008, 109-118.

[23] Chahir Zaki, How Does Trade Facilitation Affect International Trade, European Journal of Development Research, 27(1), January 2015, 156185 . 